\title{
Nutritional value and consumer properties of bakery products with fructose for diabetic nutrition
}

\author{
Vira Drobot, Anastasiia Shevchenko
}

National University of Food Technologies, Kyiv, Ukraine

Keywords:

Bakery

Fructose

Nutritional

Freshness

Diabetes

Utility

\section{Article history:}

Received 16.05.2017

Received in revised form

26.08.2017

Accepted 05.09.2017

Corresponding author:

Anastasiia Shevchenko

E-mail:

Nastyusha8@ukr.net

DOI: $10.24263 / 2304-$

974X-2017-6-3-8

\section{Abstract}

Introduction. Nutritional value and consumer properties are decisive for assessing the quality of products which are attractive for the consumer. In this paper a study of these characteristics in products for the diabetic direction is presented.

Materials and methods. The dough was prepared in an unoccupied way after the developed recipes. These characteristics were determined by the organoleptic parameters by the expert estimation method, the structural and mechanical properties of the crumb on the automated penetrometer, the degree of freshness conservation by the indexes of lidding and moisture content, distribution and forms of moisture communication by differential thermal analysis on the derivatograph, the content of aromatic substances by the amount of bisulfite binding compounds.

Results and discussion. Currently, diabetic bakery products made after common recipes have a low nutritional value and a short expiration date without loss of freshness. An expert assessment of the diabetic products developed by us «Bakery product $1 »$ and «Bakery product 2», enriched with the components of casein, powder of artichoke, cellulose of buckwheat bran, calcium citrate, magnesium, zinc and iron showed an improvement of the organoleptic qualities of the products when adding these components. The determination of the deformation of the crumb and the hydrophilic properties revealed that the developed products strung slowly due to increasing of water absorption capacity. This correlates with the better preservation of the associated moisture during storage. These products, in comparison with the control sample, contain more aromatic compounds both in the crust and in the crumb. The calculation of the nutritional value of products showed a significant increase of the nutrient content in samples with additives.

Conclusion. The developed products have a higher nutritional value and better quality characteristics, they are slowly striking. 


\section{Introduction}

The nutritional value of bread depends on the type and variety of flour, recipe additives and the moisture content of the product. Bread is well absorbed by the organism, because it has a loose elastic crumb, in which proteins are optimally denatured, starch is pasteurized, sugars are dissolved. This state of the constituents of bread makes them available for the action of enzymes of the gastrointestinal tract [1-3]. The chemical composition of bread, its taste, smell, state of proteins and carbohydrates, that form its structure, the presence of biologically active substances - vitamins, minerals in it, give high physiological value to the bread $[4,5]$. The influence of the constituents on various systems of vital activity of the organism - immune, cardiovascular, digestive, etc. forms its physiological value. However, according to the current requirements of the science of nutrition, bread products need improving their composition. There isn't the optimum ratio of proteins and carbohydrates, calcium and phosphorus in bread, there is also insufficient content of such essential amino acids as lysine, methionine, tryptophan [6]. Recently, diabetes has become widespread, but on the world market, the range of bakery products for diabetic nutrition, especially enriched with useful nutrients, is small [7-9].

At the present stage among bakery products diabetic products with a low nutritional value and a relatively high glycemic index, deprived of physiologically useful components such as complete proteins, fiber, vitamins and minerals dominate [10], [11-16]. As substitutes for sugar, polyols such as sorbitol, xylitol, mannit, etc. are mainly used. However, natural substances, in particular sugar - fructose should be preferred.

The deterioration of the quality of bakery products, and especially the products of special diabetic nutrition, is connected with the number of factors: low quality of raw materials, non-compliance with the technological process, etc. [17]. Consumer properties are determined by the chemical composition, assimilation of nutrients, energy value, biological and organoleptic characteristics of bread [18]. In the case of use of raw materials of reduced quality, errors in the technological process or in the wrong mode of storage, the consumer properties of bread are reduced [19].

The problem of drawing of bread, caused by changes in the structure of starch: retrogradation, reorganization of polymers in the amorphous region, loss of moisture and distribution of water between amorphous and crystalline zones [20].

The modern way of life prompts the necessity of making bread of long-lasting freshness. In connection with this, near the use of packaging materials, it is relevant to make supplements aimed at improving the quality of bread and slowing down its drawing. The purpose of our research was to determine the influence of the components of the recipes of developed bakery products «Bakery product 1» and «Bakery product 2» for diabetic nutrition on their consumer properties and preservation of freshness in comparison with the product without additives.

\section{Materials and methods}

\section{Materials}

The products were produced with such ratio of the recipe components, $\%$.

\section{Control sample:}

Flour - 91,3; Yeast - 2,7; Salt - 1,5; Fructose - 4,5. 


\section{Bakery product 1:}

Flour - 79,6; Yeast - 2,4; Salt - 1,2; Fructose - 4,0; Corn oil - 1,6; Mixture of calcium, zinc, magnesium and iron citrates - 0,8; Casein - 7,2; Artichoke powder - 3,2.

\section{Bakery product 2:}

Flour - 77,3; Yeast - 2,3; Salt - 1,2; Fructose - 3,9; Corn oil - 1,5; Mixture of calcium, zinc, magnesium and iron citrates - 1,4; Casein -6,2; Buckwheat fiber - 6,2.

\section{Conducting an expert assessment of organoleptic parameters of finished products}

Sampling: a medium sample was taken from a batch of products. The average sample was selected from the batch of products, its external features characterize the entire party. Organoleptic parameters were evaluated by the tasters using sensory organs.

Firstly, the color, shape, condition of the crust, and then - the smell, consistency, taste were evaluated.

\section{Determination of structural and mechanical parameters of the crumb by the penetrometer AP-4/1}

The bread is cut in a 40-mm thick slip, which is stacked on the stand of the appliance. In the beginning, the upper stem position should correspond to zero on the scale. On the immersion body the variable load is put and it is set to a position where it will touch the surface of the sample. The start button is pressed. The height of the sample at the place of deformation is recorded in units of penetration.

\section{Determination of the cockiness of the crumb}

Two pieces in the form of a parallelepiped of $5 \mathrm{~g}$ each are cut from the loaf of bread and transferred to a conical flask of $250 \mathrm{~cm}^{3}$. The content of the flask is stirred for 5 minutes on a vibrating mixer. The crumb, formed as a result of friction of two pieces, is collected and weighed on scales. The cockiness (X,\% to the weight of the crumb), is determined by the formula 1 :

$$
X=\frac{G_{1}}{G_{2}} \times 100
$$

where $\mathrm{G}_{1}$ - mass of crumb, $\mathrm{g} ; \mathrm{G}_{2}$ - the weight of bulk of bread, $\mathrm{g}$.

\section{Determination of the amount of water absorbed by the crumb of bread}

$3 \mathrm{~g}$ of crumb are chopped and weighed. Bulk is transported to the sieve and add $17 \mathrm{ml}$ of distilled water during 5 minutes from the pipette. The soaked crumb is collected and weighed. The amount of water absorbed by the crumb ( $\mathrm{V}, \%$ on dry matter), is calculated by the formula 2:

$$
V=\frac{\left(G_{1}-G_{2}\right) \times 100 \times 100}{G_{2}-(100-W)}
$$

where $\mathrm{G}_{1}$ - mass of bread after wetting, $\mathrm{g} ; \mathrm{G}_{2}$ - weight of bread bulk, $\mathrm{g}$, W - mass fraction of moisture in bread, $\%$. 


\section{Determination of the forms of bonding of moisture in bread by derivatograph Q-1500}

The essence of the method is that the sample and the standard are loaded into the working volume and heated at a constant rate. In this case, the temperature of the sample and the difference between the temperature of the sample and the standard reference temperature difference, sample mass change, and the difference in masses of the reference and working samples are measured. In two crucibles a standard sample and a test sample weighing $1 \mathrm{~g}$ is loaded. They are heated and at a rate of $1.25^{\circ} \mathrm{C} / \mathrm{min}$ in the temperature range of $20-250{ }^{\circ} \mathrm{C}$. The recording device captures the graphs. On the curve of the difference in sample masses, a clear endeavor is observed, which corresponds to the additional absorption of heat by the sample. Tangents are held to it. From the point of intersection of the tangents, the vectors are carried to the intersection with the curves of the change in mass and temperature of the sample. On a scale of mass and temperature the mass loss of the sample is determined.

Analysis of derivatograms was made according to the method of A. Litvinenko.

\section{Determination of aromatic compounds}

The methodology is to determine the bisulfite-binding compounds according to the method of R. Tokareva and V. Kretovich and is based on the ability of binding of aldehydes and some ketones by sodium bisulfite. The crumb or crust weighing $20 \mathrm{~g}$ is triturated in a mortar with $0.15 \%$ solution of sodium bisulfite and transferred quantitatively to a $200 \mathrm{~cm}^{3}$ volumetric flask. Content is brought to the mark and shaken for 10 minutes. The suspension is filtered, $20-25 \mathrm{~cm}^{3}$ of filtrate is transferred to a conical flask of $250-300 \mathrm{~cm}^{3}$ and $1 \mathrm{~cm}^{3}$ of $1 \%$ starch solution is added. The excess of bisulfite is oxidized firstly by 0.1 and then by $0.01 \mathrm{~mol} / \mathrm{dm}^{3}$ of iodine solution to a weakly violet color.

To destroy the bisulficarbonyl compounds and bring to $\mathrm{pH}$ of $8,3,25 \mathrm{~cm}^{3}$ of alkalineboron solution is added to the flask and titrated from the micro burette the isolated bisulfite $0.01 \mathrm{~mol} / \mathrm{dm}^{3}$ by iodine solution to a violet-blue color that does not disappear for $15 \mathrm{~s}$. The volume spent on titration is fixed. To the titrated solution $90-95 \%$ of the volume of 0.01 mol $/ \mathrm{dm}^{3}$ of iodine solution spent on the previous titration is added, then $25 \mathrm{~cm}^{3}$ of alkaline-boron solution is added and titrated by $0.01 \mathrm{~mol} / \mathrm{dm}^{3}$ of iodine solution until a violet blue color, which does not disappear for $15 \mathrm{~s}$. From the received titration results the data from the control analysis is subtracted.

Work out the results. The content of bisulfite binding agents, X, mg-eq per $100 \mathrm{~g}$ of dry matter, is calculated by the formula 3:

$$
X=\frac{V_{1} \times N \times V_{2} \times 100 \times 100}{V_{1} \times p \times(100-W)}
$$

where $\mathrm{V}_{1}$ - volume of $0,01 \mathrm{~mol} / \mathrm{dm}^{3}$ of iodine solution spent on titration, $\mathrm{cm}^{3} ; \mathrm{V}_{2}-$ the volume of a volumetric flask in which the weight of bread is placed, $\mathrm{cm}^{3}, \mathrm{~V}_{3}$ - the volume of the water-bisulfite extract of bread taken on the titration, $\mathrm{cm}^{3} ; \mathrm{N}-$ the concentration of iodine solution equal to $0.01 \mathrm{~mol} / \mathrm{dm}^{3}$; W - mass fraction of moisture in bread, $\%$.

\section{Calculation of the nutritional value of products}

"Nutritional value" characterizes the ability of bread to provide the physiological needs of the body in energy and basic nutrients. The integrated indicator of nutritional value is the 
"integral acceleration", which shows the percentage of compliance of the content in 100 grams of bread of each component to the daily need of the human body in it. Integral acceleration (IA) is calculated by the formula 4 :

$$
I A=\frac{G_{100 \text { gofbread }}^{\text {protin }} \times G_{\text {ofbread }}^{\text {perday }}}{G_{\text {perday }}^{\text {protein }} \times 100} \times 100
$$

\section{Statistical analysis}

The results were processed using methods of mathematical statistics using the programs Microsoft Excel 2010, Origin 8.0 and Fityc 0.9.8.

\section{Results and discussion}

The expert evaluation of the products has shown that in comparison with the control, when the enrichment of raw materials is introduced, the condition of the surface, the color of the crumb and crust, the taste and the flavor is improved, which is explained by the fact that the addition of protein in combination with sugar contributes to the more intensive reaction of melanoid formation and fermentation processes. The elasticity of the crumb is also improved, in particular due to the incorporation of corn oil.

The results of the ball assessment are summarized in the table (Table 1) and the profilograms are constructed (Figure 1).

Table 1

Average ball organoleptic score

\begin{tabular}{|c|c|c|c|c|c|c|}
\hline Product name & Shape & Surface & $\begin{array}{c}\text { Color of } \\
\text { the crust }\end{array}$ & $\begin{array}{c}\text { Condition of } \\
\text { the crumb }\end{array}$ & Taste & Flavor \\
\hline $\begin{array}{c}\text { Fructose bread } \\
\text { (Control) }\end{array}$ & $5,0 \pm 0,3$ & $4,7 \pm 0,4$ & $4,9 \pm 0,3$ & $4,4 \pm 0,3$ & $5,0 \pm 0,3$ & $4,8 \pm 0,3$ \\
\hline $\begin{array}{c}\text { «Bakery } \\
\text { product 1» }\end{array}$ & $4,8 \pm 0,3$ & $4,9 \pm 0,3$ & $4,8 \pm 0,3$ & $4,8 \pm 0,3$ & $4,8 \pm 0,3$ & $4,8 \pm 0,3$ \\
\hline $\begin{array}{c}\text { «Bakery } \\
\text { product 2» }\end{array}$ & $4,8 \pm 0,3$ & $4,8 \pm 0,3$ & $4,9 \pm 0,3$ & $4,7 \pm 0,3$ & $5,0 \pm 0,3$ & $5,0 \pm 0,3$ \\
\hline
\end{tabular}

The degree of preservation of freshness was determined by a penetrometer AP-4/1 (Table 2). Studies have shown that the general deformation of the crumb of «Bakery product 1» and «Bakery product 2» was less than in the control sample, which can be explained by the presence of food fibers in the structure of the crumb. These samples after 24 and 48 hours of storage had a better freshness by 3 and $9 \%$ and 2 and $8 \%$ respectively. In the process of storage, the percentage change in general deformation of the developed samples was less than in the control sample, which is the result of the introduction of raw materials, improves the elasticity of the crumb, has increased hydration ability and slows down the loss of moisture during storage. 


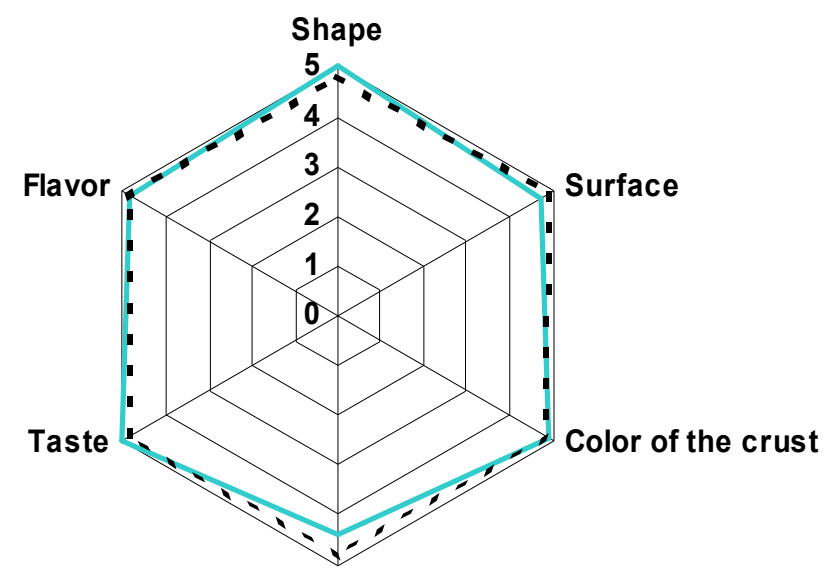

Condition of the crumb

-Fructose bread (Control)

- - - Bakery product 1

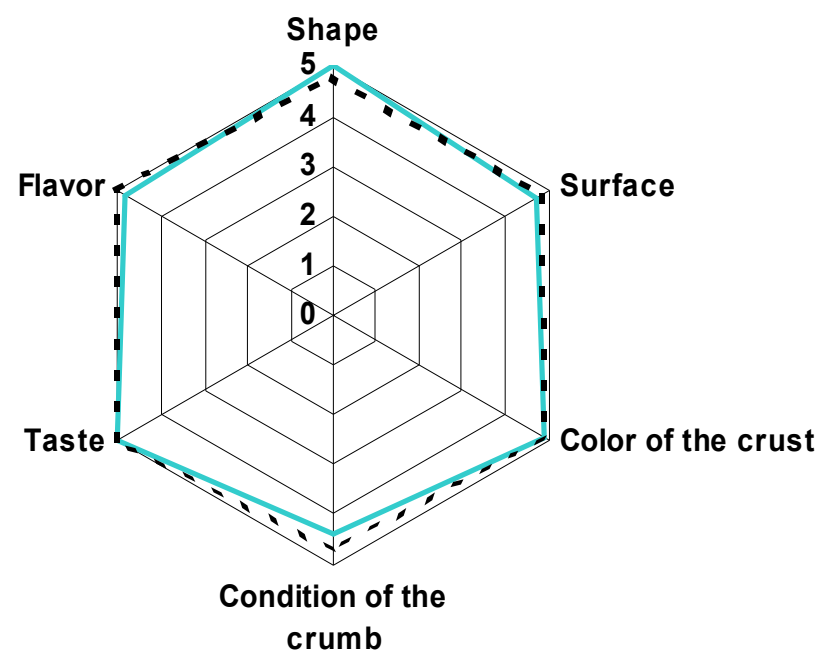

Fructose bread (Control)

- - - Bakery product 2

Figure 1. Profilograms of product quality indicators 
Table 2

Indicators of deformation of the product's crumb

\begin{tabular}{|c|c|c|c|}
\hline & $\begin{array}{c}\text { Fructose bread } \\
\text { (Control) }\end{array}$ & Bakery product 1 & Bakery product 2 \\
\hline $\begin{array}{c}\text { Deformation of the } \\
\text { crumb, unit of the } \\
\text { device } \\
\text { - after 4 hours: }\end{array}$ & \multicolumn{3}{|l}{} \\
\hline general & 66 & 59 & 57 \\
\hline - after 24 hours: & 48 & 45 & 43 \\
\hline general & 70 & 76 & 75 \\
\hline $\begin{array}{c}\text { Degree of } \\
\text { preservation of } \\
\text { freshness, }\end{array}$ & 36 & 38 & 36 \\
\hline - after 48 hours & \multicolumn{3}{|l}{} \\
\hline general & 55 & 64 & 63 \\
\hline $\begin{array}{c}\text { Degree of } \\
\text { preservation of } \\
\text { freshness, } \%\end{array}$ & \multicolumn{3}{|l}{} \\
\hline
\end{tabular}

The detention of the drawing is confirmed by a decrease of cockiness by $30-67 \%$ after 24 hours and by $23-32 \%$ after 48 hours (Figure 2), and the increased water absorption capacity of the crumb (Table 3 ).

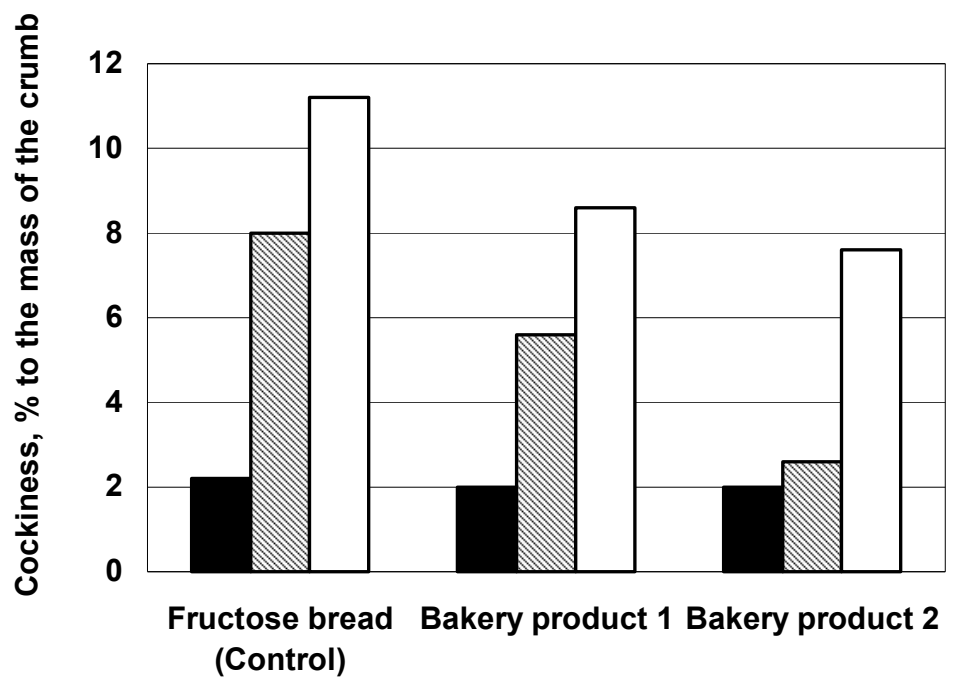

after 4 hours

\$after 24 hours

$\square$ after 48 hours

Figure 2. Cockiness of products during storage 
Water-absorbing capacity of crumb of the products, $\%$ on dry matter

\begin{tabular}{|c|c|c|c|}
\hline $\begin{array}{c}\text { Duration of } \\
\text { storage, hours }\end{array}$ & $\begin{array}{c}\text { Fructose bread } \\
\text { (Control) }\end{array}$ & $\begin{array}{c}\text { «Bakery product } \\
\text { 1» }\end{array}$ & $\begin{array}{c}\text { «Bakery product } \\
\text { 2» }\end{array}$ \\
\hline 4 & 462 & 492 & 478 \\
\hline 24 & 416 & 434 & 427 \\
\hline 48 & 320 & 390 & 378 \\
\hline
\end{tabular}

With the help of differential-thermal analysis, a determination of the forms of moisture binding in the bread crumb was made.

Derivatograms are shown on Figures 3, 4, 5.

The results of the analysis are in the Table 4.

Loss of bound moisture by the samples

Table 4

\begin{tabular}{|c|c|c|c|c|}
\hline \multirow{2}{*}{ Samples } & \multirow{2}{*}{$\begin{array}{c}\text { Duration of } \\
\text { storage, hours }\end{array}$} & \multicolumn{2}{|c|}{$\begin{array}{c}\text { Mass fraction of } \\
\text { moisture,\% to the total } \\
\text { volume }\end{array}$} & \multirow{2}{*}{$\begin{array}{c}\text { Reduced connected } \\
\text { moisture content }\end{array}$} \\
\cline { 3 - 4 } & & free & connected & \\
\hline Fructose bread & 4 & 72,0 & 28,0 & 3,9 \\
(Control) & 24 & 75,9 & 24,1 & \multirow{2}{*}{1,4} \\
\hline «Bakery & 4 & 69,2 & 30,8 & 2,0 \\
product 1» & 24 & 70,6 & 29,4 & \\
\hline «Bakery & 4 & 68,8 & 32,2 & \\
product 2» & 24 & 69,8 & 30,2 & \\
\hline
\end{tabular}

From the obtained derivatograms it is seen that during the evaporation of moisture for all samples, the peaks of the endothermic effect at certain specific temperatures are characteristic. All curves have similar nature, differing only by the size of temperature intervals corresponding to the evaporation of moisture with different levels of communication energy. The dependence of the higher content of the total amount of adsorption connected moisture with high communication energy in the samples «Bakery product $1 »$ and «Bakery product $2 »$ is seen compared with the control, which can be explained by the presence in the recipe of a greater quantity of products enriched with proteins and fibers with high hydrophilicity

As a result of the research, it was found that the storage of bread freshness correlates with a high content of connected moisture in it, which helps to slow down the processes of diffusion and bread crumbling.

An important component of the consumer value of products is taste and flavor. Their formation is conditioned by the chemical composition of the recipe components and observance of the technological process. It is believed that the main criterion that affects the formation of taste and flavor is the presence of carbonyl compounds formed during the baking process. Results of determining the content of bisulfite binding compounds are given in the Table 5. 

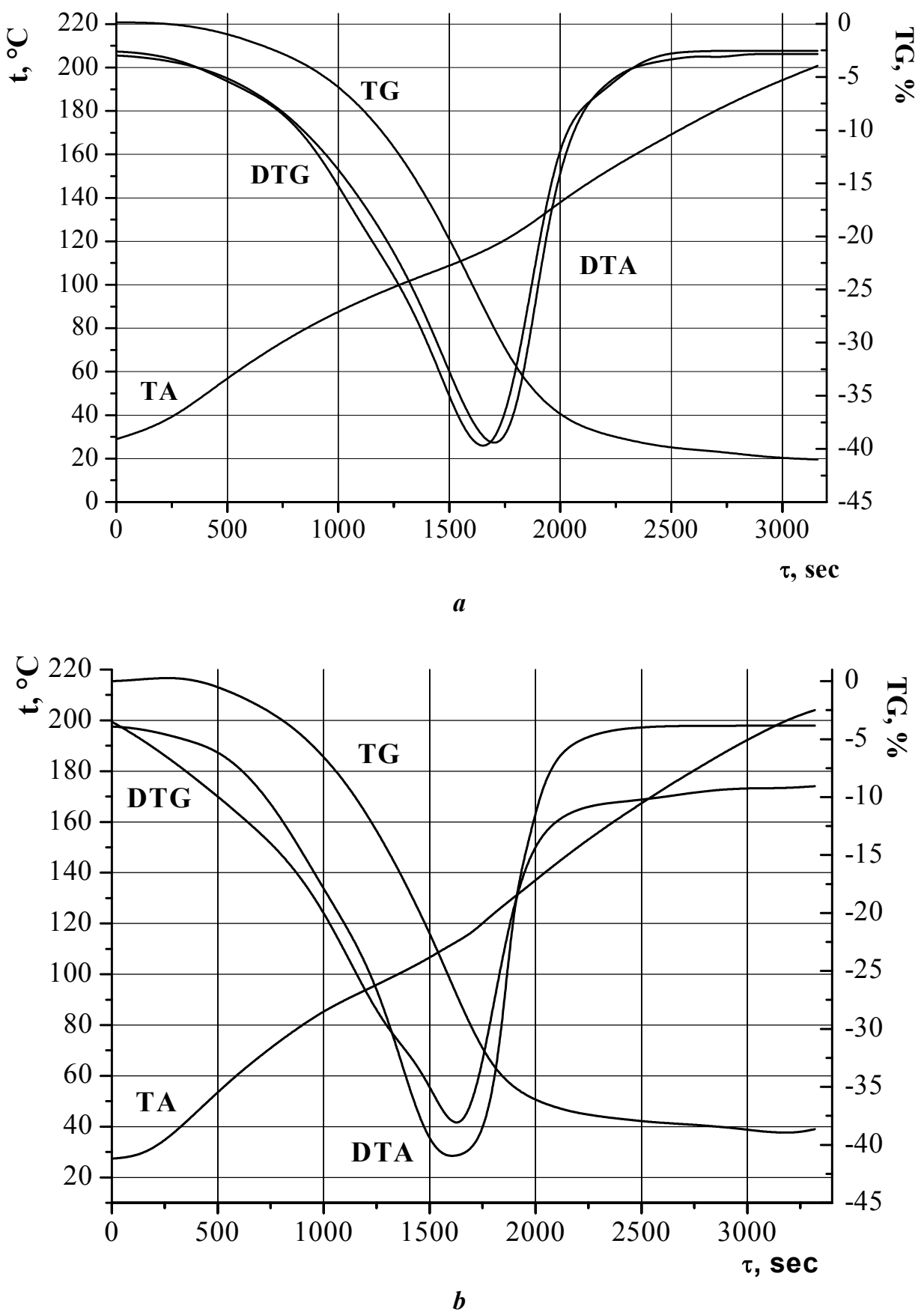

Figure 3. Derivatograms of thermolysis of bread crumb of Control sample: $a$-after 4 hours, $b$-after 24 hours. 

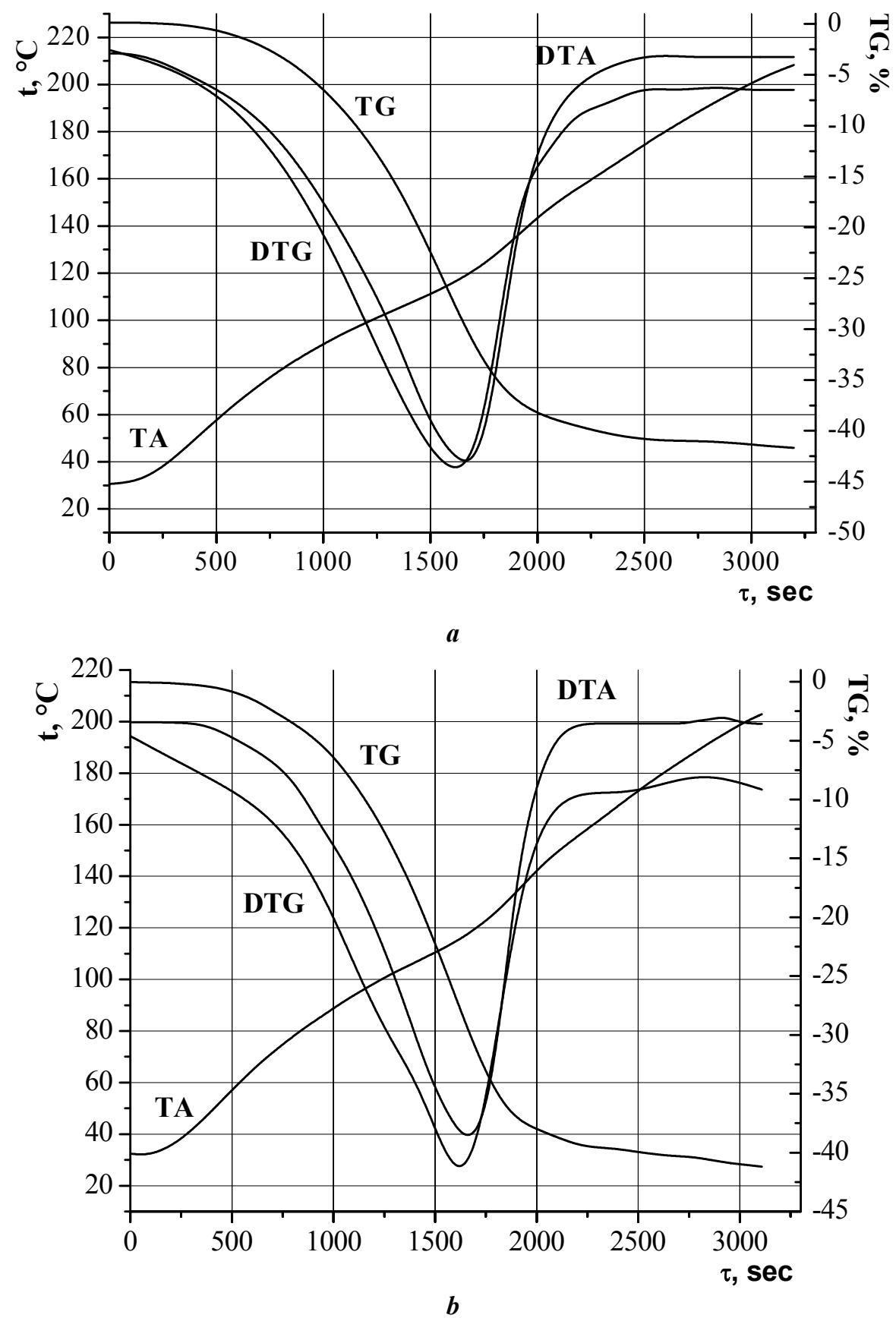

Figure 4. Derivatograms of thermolysis of bread crumb of «Bakery product $1 »$ : $a$-after 4 hours, $b$ - after 24 hours. 

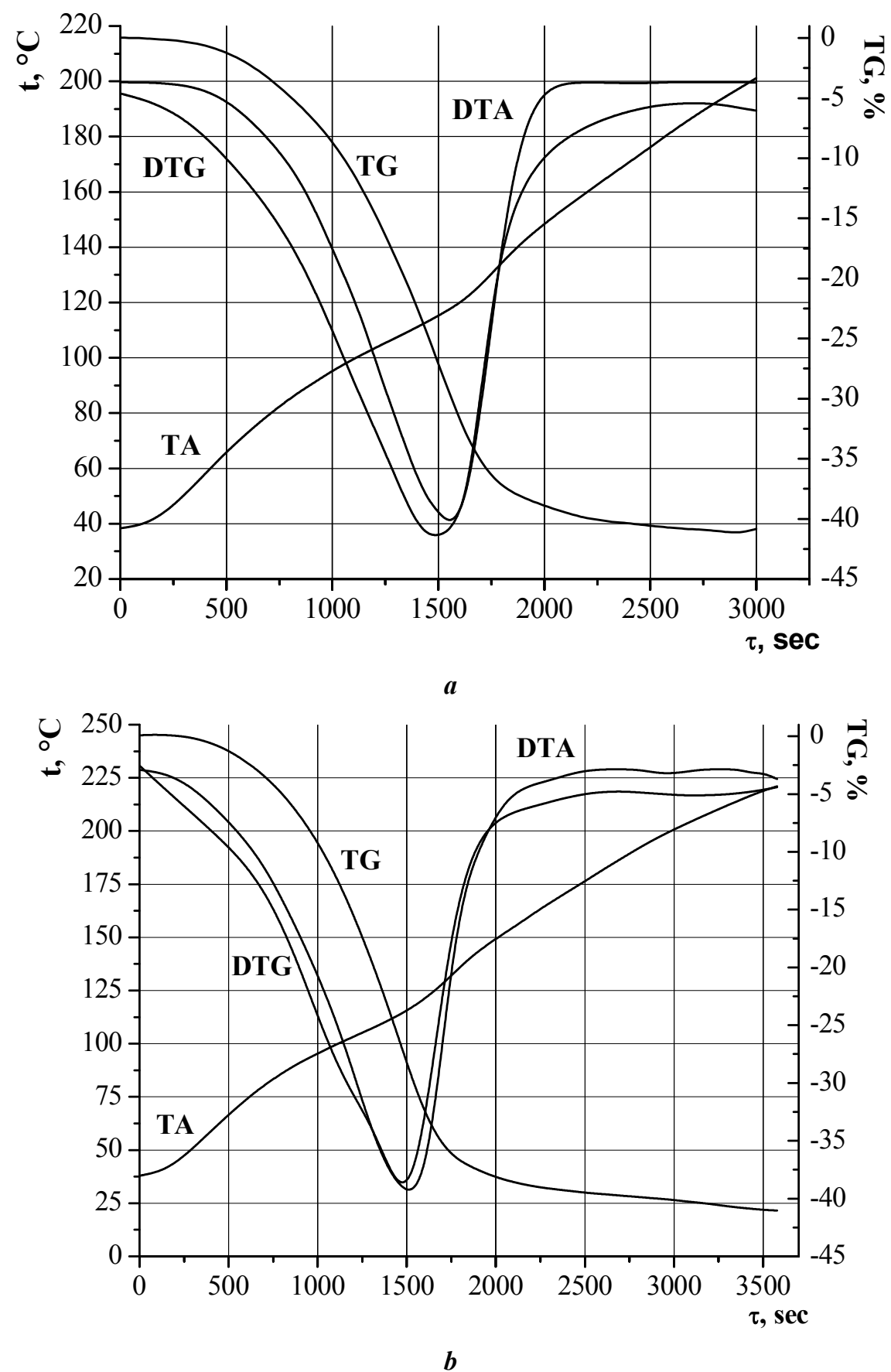

Figure 5. Derivatograms of thermolysis of bread crumb of «Bakery product 2»: $a$-after 4 hours, $b$-after 24 hours. 
Content of bisulfite binding agents, mg-eq/100 $\mathrm{g}$ of bread

\begin{tabular}{|c|c|c|c|}
\hline $\begin{array}{c}\text { Content of bisulfite } \\
\text { binding agents, mg- } \\
\text { eq/100 g of bread }\end{array}$ & $\begin{array}{c}\text { Fructose bread } \\
\text { (Control) }\end{array}$ & «Bakery product 1» & «Bakery product 2» \\
\hline After 4 hours & \multicolumn{3}{|c|}{} \\
\hline -in the crust & 25,7 & 32,3 & 29,4 \\
-in a crumb & 5,3 & 6,4 & 6,1 \\
\hline After 4 hours & 22,8 & 26,4 & 24,2 \\
\hline -in the crust & 5,6 & 6,6 & 6,3 \\
\hline -in a crumb & 18,2 & 21,3 & 20,1 \\
\hline After 48 hours & 4,9 & 5,9 & 5,6 \\
\hline -in the crust & \multicolumn{3}{|c|}{} \\
\hline -in a crumb &
\end{tabular}

Studies have shown that in the developed samples after 4 hours of storage the amount of aromatics is greater than the control: in the crust of «Bakery product 1 » by $25,6 \%$, in the crumb - by $20,7 \%$, in «Bakery product 2 » - in the crust by $14.4 \%$, in the crumb - by $15 \%$. In the process of storage, the products had less loss of bisulfite-binding agents.

The calculation of the nutritional value of products (Table 6) showed a significant increase of nutrient content in samples with additives.

\section{Nutritional value of products}

Table 6

\begin{tabular}{|c|c|c|c|c|c|c|c|c|c|}
\hline \multirow[b]{2}{*}{$\begin{array}{l}\text { Nutrient content in } 100 \mathrm{~g} \text { of } \\
\text { products }\end{array}$} & \multirow[b]{2}{*}{$\begin{array}{l}\tilde{D}_{0}^{0} \\
\frac{0}{0} \\
0 \\
0\end{array}$} & \multirow{2}{*}{ 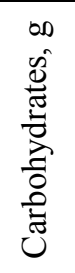 } & \multirow[b]{2}{*}{ 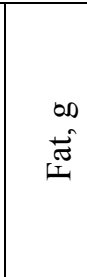 } & \multirow{2}{*}{\multicolumn{2}{|c|}{ 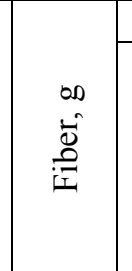 }} & \multicolumn{4}{|c|}{ Mineral substances, $\mathrm{mg}$} \\
\hline & & & & & & $\mathrm{Mg}$ & $\mathrm{Ca}$ & $\mathrm{Zn}$ & $\mathrm{Fe}$ \\
\hline Fructose bread (Control) & 6,4 & 44,8 & 0,7 & 0 , & 7 & 0,01 & 0,014 & 0,006 & 0,01 \\
\hline «Bakery product 1» & 7,7 & 30,2 & 1,4 & 1 , & 6 & 7,8 & 11,1 & 0,4 & 0,6 \\
\hline «Bakery product $2 »$ & 7,8 & 31,8 & 1,5 & 1, & 8 & 8,0 & 11,7 & 0,4 & 0,6 \\
\hline $\begin{array}{c}\text { Daily requirement for the } 1^{\text {st }} \\
\text { group of work intensity } \\
\text { at the age of } 30-39 \text { years }\end{array}$ & 61 & 368 & 64 & 25 & & 400 & 1200 & 17 & 15 \\
\hline \multicolumn{10}{|l|}{$\begin{array}{c}\text { Integral accelerator when } \\
\text { consuming } 100 \mathrm{~g} \text { of bread, } \%\end{array}$} \\
\hline Fructose bread (Control) & & & 10,2 & 0,8 & 2,8 & 0,3 & 1,2 & 0,5 & 0,6 \\
\hline «Bakery product $1 »$ & & & 6,8 & 1,8 & 6,5 & 17,8 & 16,7 & 18,6 & 18,0 \\
\hline «Bakery product $2 »$ & & & 7,2 & 1,9 & 7,4 & 18,0 & 17,7 & 18,3 & 18,2 \\
\hline
\end{tabular}




\section{Conclusion}

It is established that the products enriched with the ingredients of casein, artichoke powder, buckwheat fiber and calcium, zinc, magnesium and iron citrates, «Bakery product $1 »$ and «Bakery product $2 »$, have higher nutritional value than the control sample, which is confirmed by the percentage of daily nutrient requirement. The products have better quality characteristics and keep freshness longer during storage.

\section{References}

1. Kwame O.D., Yu-Jiao L., Zhi-En P. (2017), Evaluating the nutritional and sensory quality of bread, cookies and noodles made from wheat supplemented with root tuber flour, British Food Journal, 119(4), pp.895-908.

2. Dewettincka K., Bockstaele F.V., Kuhne B., Van de Walle D., Courtens T.M., Gellynck X. (2008), Nutritional value of bread: Influence of processing, food interaction and consumer perception, Journal of Cereal Science, 48(2), pp. 243-257.

3. Gellynck X., Kuhne B., Bockstaele F.V., Van de Walle D., Dewettinck K. (2009), Consumer perception of bread quality, Appetite, 53(1), pp. 16-23.

4. Kumar P., Yadava R.K., Gollen B., Kumar S., Verma R.K., Yadav S. (2011), Nutritional Contents and Medicinal Properties of Wheat: A Review, Life Sciences and Medicine Research, pp. 1-10.

5. Brinch-Pedersen H., Borg S., Tauris B., Holm P.B. (2007), Molecular genetic approaches to increasing mineral availability and vitamin content of cereals, Journal of Cereal Science, 46, pp.308-326.

6. Rosell C.M. (2007), Vitamin and mineral fortification of bread, Technology of Functional Cereal Products, Cambridge, UK: Woodhead, pp. 336-361.

7. Haripriya S., Premakumari S., (2010). Effect of wheat bran on diabetic subjects, Indian Journal of Science and Technology, 3(3), pp. 284-286.

8. Nathan D.M. (2010), Navigating the choices for the diabetes prevention, N. Engl. J. Med., pp. 1-3.

9. Mohamed S. (2014) Functional food against metabolic syndrome (obesity, diabetes, hypertension and dislipidemia) and cardiovascular diseases, Trends in Food Science and Technology, 35, pp. 114-128.

10. Angioloni A., Collar C. (2011) Physicochemical and nutritional properties of reduced caloric density high-fibre breads, LWT-Food Science and Technology, 44, pp. 747758.

11. Vitaglione P., Napolitano A., Fogliano V. (2008), Cereal dietary fibre: a natural functional ingredient to deliver phenolic compounds into the gut, Trends in Food Science and Technology, 19, pp. 451-463.

12. Kurek M., Wyrwisz J. (2015), The Application of Dietary Fiber in Bread Products, $J$ Food Process Technol, 6(5), pp. 447-451.

13. Yangilar F. (2013), The application of dietary fibre in food industry: structural features, effects on health and definition, obtaining and analysis of dietary fibre: a review, Journal of Food and Nutrition Research, 1, pp. 13-23.

14. Sivam A.S., Sun-Waterhouse D., Quek S.Y., Perera C.O. (2010), Properties of bread dough with added fibre polysaccharides and phenolic antioxidants: A review, Journal of Food Science, 75, pp. 163-174.

15. Dhingra D. (2012), Dietary fibre in foods: a review, Journal of Food Science Technolnology, 49, pp. 255-266. 
16. Almeida E., Chang Y., Steel C. (2012), Dietary fibre sources in bread: Influence on technological quality, LWT- Food Science and Technology, 50, pp. 545-553.

17. Eleazu C., Eleazu K, Aniedu C., Amajor J., Ikpeama A., Ebenzer I. (2014), Effect of Partial Replacement of Wheat Flour with High Quality Cassava Flour on the Chemical Composition, Antioxidant Activity, Sensory Quality, and Microbial Quality of Bread, Prev Nutr Food Sci., 19(2), pp. 115-123.

18. Heenan S.P., Dufour J.-P., Hamid N., Harvey W., Delahunty C.M. (2008), The sensory quality of fresh bread: Descriptive attributes and consumer perceptions, Food Research International, 41(10), pp. 989-997.

19. Dewettinck K., Van Bockstaele F., Kuhne B., Van de Walle D., Courtens T.M., Gellynck X. (2008), Nutritional value of bread: Influence of processing, food interaction and consumer perception, Journal of Cereal Science, 48, pp. 243-257.

20. Tamara R., Hadnađev D., Dokić L.P., Hadnađev M.S., Pojić M. M., Rakita S.M., Torbica A. M. (2013), Changes in quality parameters of bread supplemented with OSA starch during storage, Food \& Feed Research, 40(2), pp. 101-108. 